\title{
Synthesis and Characterization of Novel Tetrazole Derivatives and Evaluation of Their Anti-candidal Activity
}

\author{
Hiba Maher Tawfeeq ${ }^{1}$, Rasim Farraj Muslim²*, Obaid Hasan Abid ${ }^{3}$, \\ Mustafa Nadhim Owaid ${ }^{4}$ \\ 1 University Of Anbar, Department of Chemistry, College of Education for Pure Sciences, Anbar/Ramadi, Iraq \\ 2 University Of Anbar, Department of Ecology, College of Applied Sciences, Anbar/Hit, Iraq \\ 3 University of Fallujah, Department of Scientific Affairs and Graduate Studies, Anbar/Fallujah, Iraq \\ 4 Ministry of Education, Department of Heet Education, Anbar/Hit, Iraq
}

\begin{abstract}
This research includes synthesis of new heterocycles containing disubstituted Tetrazole derivatives. Imine compounds were synthesized by reaction of primary aromatic amines with various substituted benzaldehydes in the presence of glacial acetic acid as catalyst in absolute ethanol to obtain new imine compounds $\mathrm{O}_{1}-\mathrm{O}_{5}$. The novel five-membered heterocycles as Tetrazole derivatives $\mathrm{O}_{6}-\mathrm{O}_{10}$ were obtained from treatment of each new imine compounds with sodium azide compound. Newly synthesized compounds were identified via spectral methods (FTIR, ${ }^{1} \mathrm{H}-\mathrm{NMR}$ and ${ }^{13} \mathrm{C}-\mathrm{NMR}$ ) spectra and some physical properties. $\mathrm{O}_{6}$ is the best derivative that has significantly $(p<0.01)$ recorded a stronger influence to inhibit the growth of Candida guilliermondii at an average of the zone of inhibition 14.0 $\mathrm{mm}$. While, $\mathrm{O}_{9}$ derivative recorded the lowest zone of inhibition $7.3 \mathrm{~mm}$ toward the same clinical fungal pathogen. The present work may be helpful in designing more potential antibacterial and antifungal agents for therapeutic use in the future.
\end{abstract}

Keywords: Tetrazole, Candida sp., anti-candidal, imine compounds, sodium azide.

\section{INTRODUCTION}

Imine compounds are class of the compounds which contain $-\mathrm{HC}=\mathrm{N}$ - group, they are usually synthesizing by the condensation of a primary aromatic amino

\footnotetext{
${ }^{\star}$ Corresponding Author: Mustafa Nadhim Owaid, e-mail: dr.rasim92hmts@gmail.com Hiba Maher Tawfeeq ORCID Number: 0000-0002-5525-568X Rasim Farraj Muslim ORCID Number: 0000-0002-8273-2429 Obaid Hasan Abid ORCID Number: 0000-0001-8473-4842 Mustafa Nadhim Owaid ORCID Number: 0000-0001-9005-4368 (Received 14 January 2019, accepted 20 May 2019)
} 
group with an active carbonyl aromatic aldehyde. They are versatile precursors in the synthesis of organic, bio-organic, organometallic and industrial compounds via ring closure, cycloaddition and replacement reactions. ${ }^{1-4}$ Imine compounds were discovered by a German chemist, Nobel prize winner, Hugo Schiff in $1864 .{ }^{5}$ Imine compounds produced from the reaction between ketone or aldehyde compounds with amine compounds. ${ }^{6}$ In the presence of perchloric acid (Scheme 1) the reaction of 4-fluorobenzaldehyde with 1-benzylpiperidin4-amine gives the next product. ${ }^{7}$

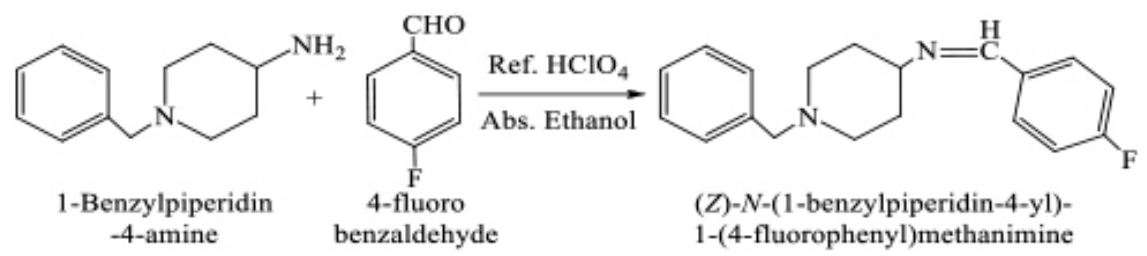

Scheme 1. The effect of perchloric acid on imine compound formation

The reaction of pyridine-2-amine with 4-(dimethyl amino) benzaldehyde (Scheme 2) produces the imine compound. ${ }^{8}$

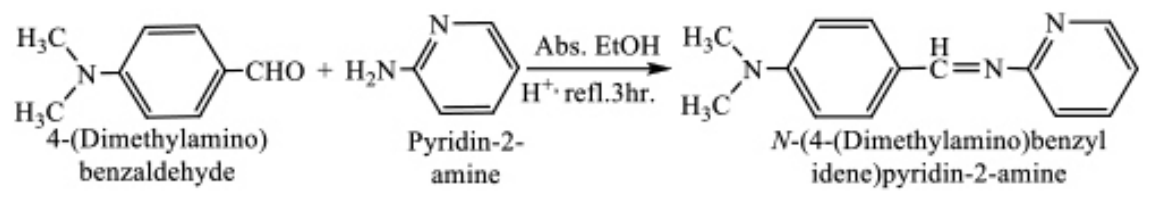

Scheme 2. Using glacial acetic acid to prepare the imine compound

One of the most important chemical compounds is sodium azide, which has been used in many fields including its effect on germination. ${ }^{9}$ Due to its great importance, it was used in the preparation of compounds called tetrazoles. Tetrazoles are a class of synthetic organic heterocyclic compounds consist of five-member ring of four nitrogen atoms and one carbon atom (Scheme 3). ${ }^{10}$<smiles>c1nnn[nH]1</smiles>

Scheme 3. Structure of tetrazole ring 
Synthesis of tetrazole derivatives is an important task in modern medicinal chemistry. ${ }^{11}$ Tetrazoles are class of heterocycles that have received attention due to their wide range of applications. ${ }^{12}$ Pharmacologically, because of the effect of gram-negative or gram-positive bacteria on the health of human, thus some potential drugs/products must be synthesized..$^{13,14}$ Tetrazole contains compounds reported to possess diverse chemotherapeutic activities as antibacterial, ${ }^{15}$ and antifungal. ${ }^{16}$ Example of one of tetrazole derivatives is the product from the reaction between imine compound (N,N'-([1,1'-biphenyl $]-4,4$ '- diyl) bis (1- (pyridine - 4 - yl) methanimine)) and sodium azide (Scheme 4) ${ }^{17}$

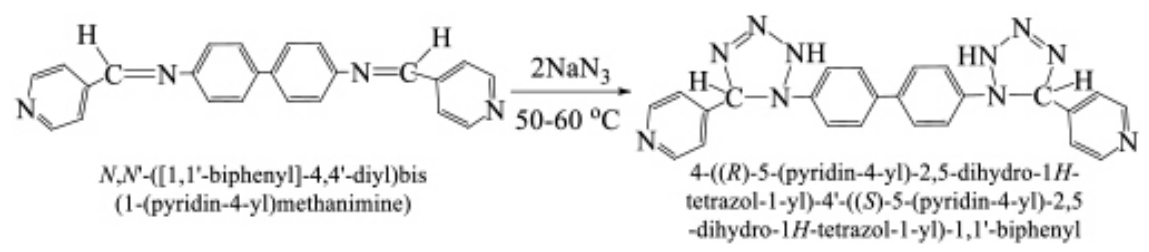

Scheme 4. Synthesized of 2,5-dihydro-1H-tetrazol derivative

Tetrazole derivatives of type of 5-phenyl-1H-tetrazol-1-yl) thiazetidine dioxide prepared from the next reaction (Scheme 5), ${ }^{18}$ below:

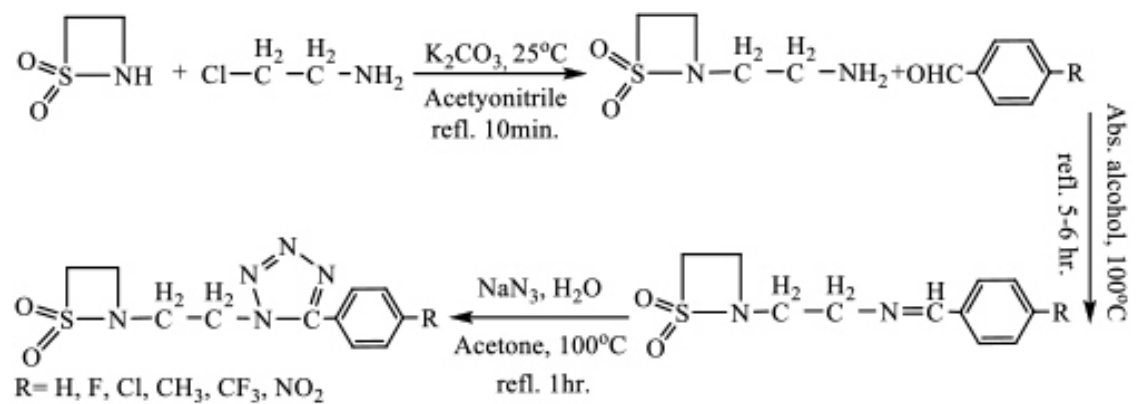

Scheme 5. Potassium carbonate in tetrazole derivatives synthesis

This study aims to prepare tetrazole derivatives for first time and investigate their activity against pathogenic fungi, Candida spp. in vitro. 


\section{METHODOLOGY}

\section{Materials}

All chemicals were obtained and purchased from Sigma Aldrich.

\section{General procedure for the synthesis of imine compounds $\mathrm{O}_{1}-\mathrm{O}_{5}$}

Equimolar mixtures 0.02 mole of aldehydes and aromatic amines and trace of glacial acetic acid dissolved in $25 \mathrm{ml}$ absolute ethanol was placed in a 100-ml round-bottom flask equipped with condenser and stirrer bar. The mixture was allowed to react at reflux (at the boiling temperature of absolute ethanol) for $4 \mathrm{hr}$, then allowed to cool down to the room temperature, whereby a crystalline solid was separated out. The solid product was recrystallized twice from absolute ethanol. ${ }^{19-22}$ The structural formulae, names, melting points, colors, and percentage of yields for the synthesized imine compounds are recorded in Table 1.

Table 1. Structural formula, nomenclature, melting points, percentages of yield and colors of imine compounds $\mathrm{O}_{1}-\mathrm{O}_{5}$

\begin{tabular}{|c|c|c|c|c|c|}
\hline $\begin{array}{l}\text { Comp. } \\
\text { Code }\end{array}$ & Structural formula & Nomenclature & $\begin{array}{c}\text { Yield } \\
\%\end{array}$ & $\begin{array}{c}\text { m.p. } \\
{ }^{\circ} \mathrm{C}\end{array}$ & Color \\
\hline $0_{1}$ & & $\begin{array}{l}\text { (E)-5-((4,6-dimethyl } \\
\text { pyrimidin-2- } \\
\text { ylimino)methyl)-2- } \\
\text { methoxyphenol }\end{array}$ & $68 \%$ & $78-80$ & Tan \\
\hline $\mathrm{O}_{2}$ & & $\begin{array}{c}(\mathrm{E})-1-(2,4- \\
\text { dinitrophenyl)-2-(4- } \\
\text { nitrobenzylidene) } \\
\text { hydrazine }\end{array}$ & $81 \%$ & $\begin{array}{c}291- \\
293\end{array}$ & Orange \\
\hline $\mathrm{O}_{3}$ & & $\begin{array}{c}(\mathrm{E})-4-(4- \\
\text { ethoxybenzylidene } \\
\text { amino)-1,5-dimethyl- } \\
\text { 2-ph enyl-1H-pyrazol- } \\
3(2 \mathrm{H}) \text {-one }\end{array}$ & $90 \%$ & $\begin{array}{l}212- \\
214\end{array}$ & $\begin{array}{l}\text { Bright } \\
\text { yellow }\end{array}$ \\
\hline $\mathrm{O}_{4}$ & $\mathrm{H}_{3} \mathrm{C}$ & $\begin{array}{c}\text { 4-(5-chloro-2- } \\
\text { hydroxy benzyl } \\
\text { ideneamino)-1,5- } \\
\text { dimethyl -2-phenyl- } \\
\text { 1H-pyrazol-3(2H)-one }\end{array}$ & $89 \%$ & $\begin{array}{c}138- \\
140\end{array}$ & $\begin{array}{l}\text { Bright } \\
\text { pale } \\
\text { yellow }\end{array}$ \\
\hline $0_{5}$ & & $\begin{array}{l}\text { (E)-2-((p-tolylimino) } \\
\text { methyl) phenol }\end{array}$ & $87 \%$ & $94-96$ & $\begin{array}{l}\text { Bright } \\
\text { yellow }\end{array}$ \\
\hline
\end{tabular}




\section{General procedure for the synthesis of tetrazole derivatives $\mathrm{O}_{6}-\mathrm{O}_{10}$}

Equimolar mixtures 0.01 mole of imine compounds and sodium azide dissolved in $20 \mathrm{ml}$ of tetrahydrofuran and $2 \mathrm{ml}$ of distilled water and refluxed the mixture (at the boiling temperature of tetrahydrofuran and distilled water) for $4 \mathrm{hr}$ and left to stand for $24 \mathrm{hr}$. The solid product was precipitated, filtered off and recrystallized from absolute ethanol. ${ }^{23,24}$ The structural formulae, names, melting points, colors, and percentage yields for the synthesized tetrazole derivatives are presented in table 2. Melting points were recorded on electrothermal melting point apparatus (uncorrected). FT-IR spectra were recorded at the room temperature from (4000-400) $\mathrm{cm}^{-1}$ with $\mathrm{KBr}$ disc by infrared spectrophotometer model tensor 27 Bruker Co., Germany. The ${ }^{1} \mathrm{H}-\mathrm{NMR}$ and ${ }^{13} \mathrm{C}-$ NMR spectra were recorded by Bruker Ac-30oMHz spectrometer, it making sure from the purity and reaction occur of synthesized derivatives $\mathrm{O}_{6}-\mathrm{O}_{10}$ by the comparison between the physical measurements (Table 1) of $\mathrm{O}_{1}-\mathrm{O}_{5}$ and the physical measurements of $\mathrm{O}_{6}-\mathrm{O}_{10}$ (Table 2) and between FT-IR spectra of $\mathrm{O}_{1}$ $\mathrm{O}_{5}$ (Table 3) and FT-IR spectra of $\mathrm{O}_{6}-\mathrm{O}_{10}$ (Table 4).

Table 2. Structural formula, nomenclature, melting points, percentages of yield and colors of tetrazole derivatives $\mathrm{O}_{6}-\mathrm{O}_{10}$

\begin{tabular}{|c|c|c|c|c|c|}
\hline $\begin{array}{c}\text { Comp. } \\
\text { code }\end{array}$ & Structural formula & Nomenclature & $\begin{array}{c}\text { Yield } \\
\%\end{array}$ & $\underset{{ }^{\circ} \mathrm{C}}{\mathrm{m.p}}$ & Color \\
\hline $0_{6}$ & & $\begin{array}{c}\text { 5-(1-(4,6-dimethylpyrimi } \\
\text { din-2-yl)-4,5-dihydro-1H- } \\
\text { tetrazol -5-yl)-2-methoxy } \\
\text { phenol }\end{array}$ & $81 \%$ & $\begin{array}{l}107- \\
109\end{array}$ & $\begin{array}{l}\text { Bright } \\
\text { Pale } \\
\text { yellow }\end{array}$ \\
\hline $0_{7}$ & & $\begin{array}{l}\mathrm{N}-(2,4-\text { dinitrophenyl)- } \\
\text { 5-(4-nitrophenyl)-4,5-di } \\
\text { hydro-1H-tetrazol-1- } \\
\text { amine }\end{array}$ & $89 \%$ & $>300$ & $\begin{array}{l}\text { Pale } \\
\text { Orange }\end{array}$ \\
\hline $\mathrm{O}_{8}$ & & $\begin{array}{l}\text { 5-(4-chlorophenyl)-4- } \\
\text { (1,5-dimethyl-3-oxo- } \\
\text { 2-phenyl-2,3-dihydro- } \\
\text { 1H-pyrazol-4-yl)-4,5- } \\
\text { dihydrotetrazol-1-ide }\end{array}$ & $93 \%$ & $\begin{array}{c}242- \\
244\end{array}$ & $\begin{array}{l}\text { Pale } \\
\text { yellow }\end{array}$ \\
\hline $\mathrm{O}_{9}$ & & $\begin{array}{l}\text { 4-(5-(5-chloro-2-hydroxy } \\
\text { phe nyl)-4,5-dihydro- } \\
\text { 1H-tetrazol-1-yl)-1,5- } \\
\text { dimethyl -2-phenyl-1H- } \\
\text { pyrazol-3(2H)-one }\end{array}$ & $85 \%$ & $\begin{array}{c}169- \\
171\end{array}$ & $\begin{array}{l}\text { Pale } \\
\text { yellow }\end{array}$ \\
\hline $0_{10}$ & & $\begin{array}{c}\text { R)-2-(1-p-tolyl-4,5-di } \\
\text { hydro-1H-tetrazol-5-yl) } \\
\text { phenol }\end{array}$ & $84 \%$ & $\begin{array}{c}119- \\
120\end{array}$ & $\begin{array}{l}\text { Bright } \\
\text { Golden }\end{array}$ \\
\hline
\end{tabular}




\section{Anti-Candidal activity}

This test was achieved in vitro to investigate inhibitory effects of the synthesized tetrazole derivatives using well diffusion method on Muller-Hinton agar. This experiment was done as mentioned by Owaid et al. ${ }^{25,26}$ Four milligrams of each tetrazole derivative was dissolved in DMSO and applied separately as 4 $\mathrm{mg} /$ well ( $6 \mathrm{~mm}$-well). After $18 \mathrm{hr}$ of incubation at $37^{\circ} \mathrm{C}$, the zone of inhibition was taken using the ruler in millimeters.

\section{Statistical Analysis}

The data (triplicates) were analyzed by one-way analysis of variance using ANOVA table by SAS program for Windows, version 9.0, SAS Institute Inc., USA. The significance of differences was calculated using Duncan's Multiple Range Test (DMRT). Probability value least than $1 \%$ was considered to be statistically significant.

\section{RESULTS AND DISCUSSION}

\section{Imine compounds $\mathrm{O}_{1}-\mathrm{O}_{5}$}

Imine compounds (Scheme 6) were synthesized from commercially available aromatic aldehydes and primary amines and identified by their melting points, and FT-IR. The FT-IR spectra showed the appearance of the stretching absorption bands of azomethine $(\mathrm{C}=\mathrm{N})$ at $1591-1669 \mathrm{~cm}^{-1}, 27,28$ beside the characteristic bands of the residual groups in the structure Table 3. See Figs. 1 and 2.

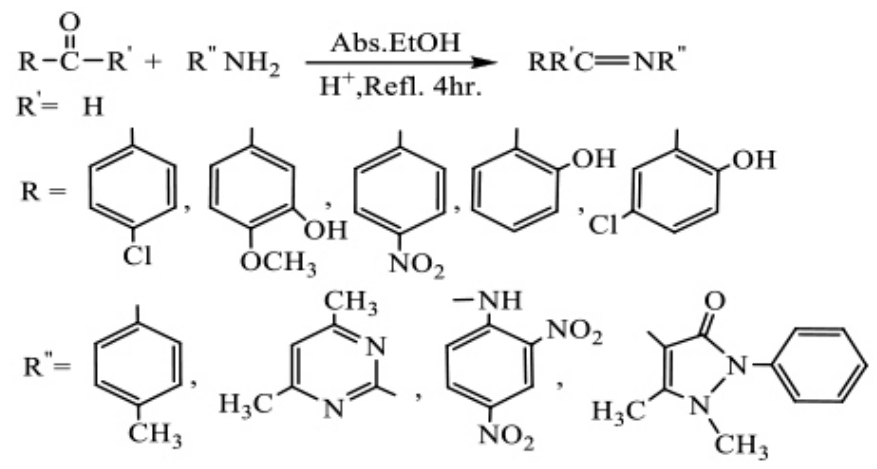

Scheme 6. Structure of the synthesized imine compounds 
Table 3. FT-IR spectra of imine compounds $\mathrm{O}_{1}-\mathrm{O}_{5}$

\begin{tabular}{|c|c|c|c|c|c|c|c|}
\hline \multicolumn{8}{|c|}{ FT-IR, $n\left(\mathrm{~cm}^{-1}\right)$} \\
\hline \multirow{2}{*}{$\begin{array}{l}\text { Comp. } \\
\text { Code }\end{array}$} & \multirow{2}{*}{$\mathrm{C}=\mathrm{N}$} & \multirow{2}{*}{$\begin{array}{c}\mathrm{C}=\mathrm{C} \\
\text { Aromatic }\end{array}$} & \multicolumn{2}{|c|}{$\mathrm{C}-\mathrm{H}$} & \multicolumn{2}{|c|}{ C-H Ali. } & \multirow{2}{*}{ Others } \\
\hline & & & Aromatic & Alkene & Asymmetric & symmetric & \\
\hline $0_{1}$ & 1669 & 1510 & 3000 & 3045 & 2974 & 2941 & $\begin{array}{c}\text { 0-H b3309, } \\
\mathrm{C}=\mathrm{N} \text { yrimidine } 1547\end{array}$ \\
\hline $\mathrm{O}_{2}$ & 1610 & 1572 & 3042 & 3089 & -- & -- & $\begin{array}{c}\mathrm{NO}_{2} 1505,1322 \\
\mathrm{~N}-\mathrm{H} 3277\end{array}$ \\
\hline $\mathrm{O}_{3}$ & 1591 & 1569 & 3044 & 3067 & 2983 & 2875 & $\mathrm{C}=0$ 1645, C-Cl 829 \\
\hline $0_{4}$ & 1594 & 1559 & 3044 & 3075 & 2983 & 2874 & $\begin{array}{c}\mathrm{C}=0 \text { 1634, C-Cl } 815 \\
\text { 0-H b3450 }\end{array}$ \\
\hline $0_{5}$ & 1614 & 1566 & 3046 & 3079 & 2980 & 2867 & 0-H b3375 \\
\hline
\end{tabular}

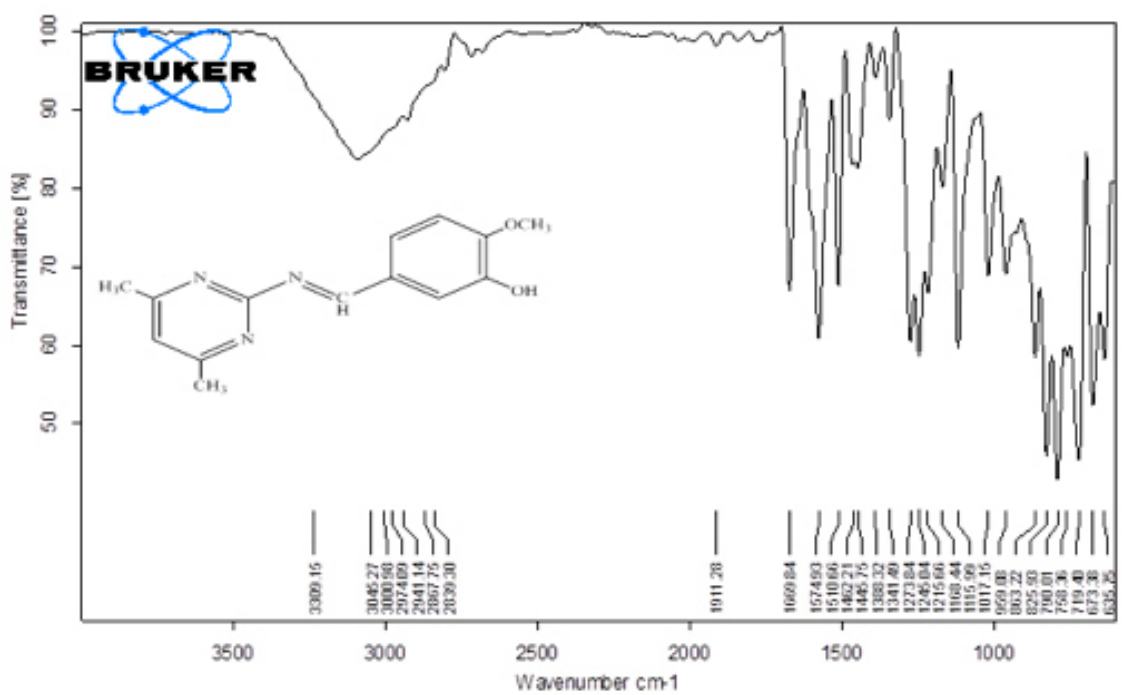

Figure 1. FT-IR spectra of $0_{1}$ 


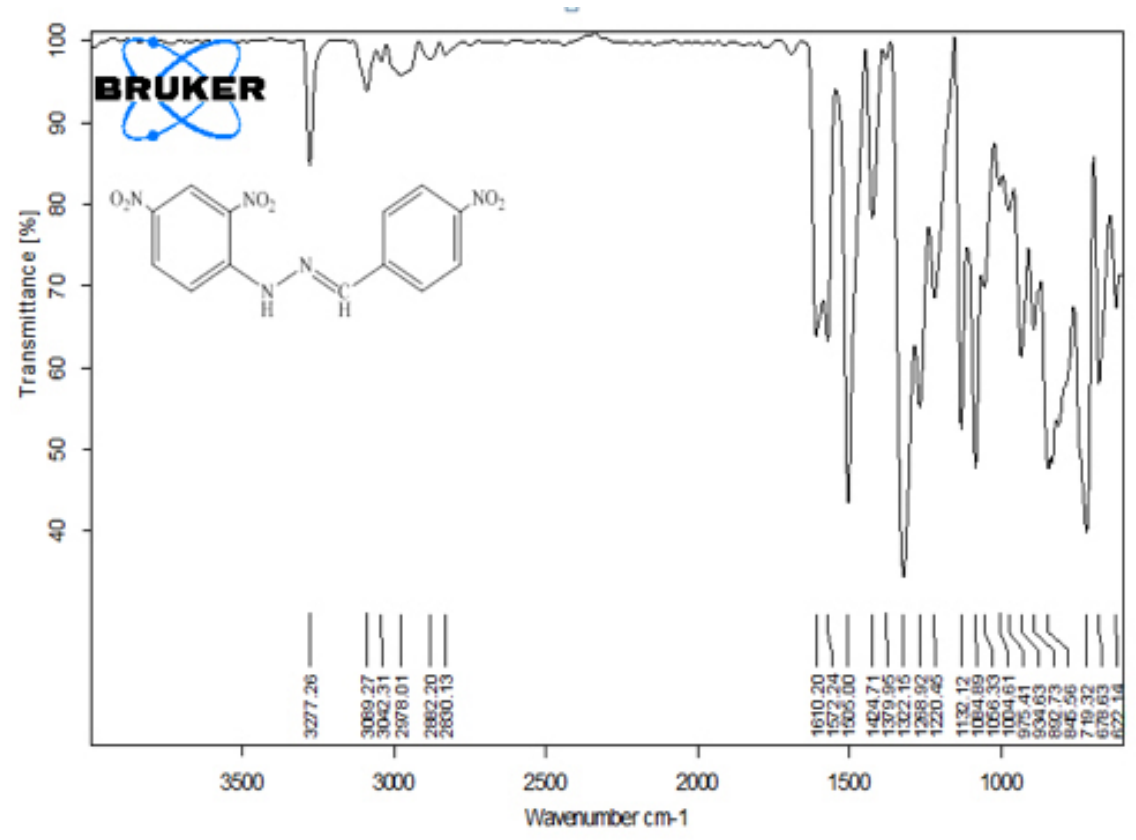

Figure 2. FT-IR spectra of $\mathrm{O}_{2}$

The physical properties and FT-IR spectra of imine compounds $\mathrm{O}_{1}-\mathrm{O}_{5}$ prove the synthesis processes, Mechanism of imine compounds formation represented in the following reaction. ${ }^{29,30}$ See scheme 7.

$1-$

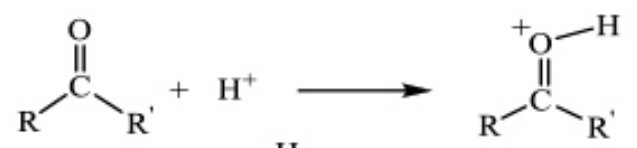

2-

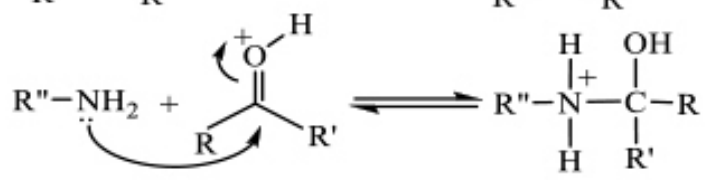

3-<smiles>[R2]Nc1ccccc1[NH2+][R2]</smiles><smiles>[R]C([R])(O)N[R]#CC=[NH2+]</smiles>

Carbinolamene

4-

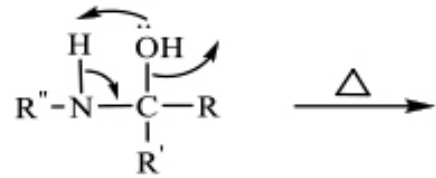<smiles>[R]N=C([R])[NH2+]O</smiles>

Azomethine

Scheme 7. Mechanism of imine compounds formation 


\section{Tetrazole derivatives $\mathrm{O}_{6}-\mathrm{O}_{10}$}

The synthesis of tetrazole derivatives was achieved by the reaction of imine and sodium azide. Their melting points identified the resulted products. FTIR spectra of the products (table 4) showed characteristic absorption band at 1272-1301, 1022-1089 and 1484-1509 $\mathrm{cm}^{-1}$ as an indicative of C-N, N-N and $\mathrm{N}=\mathrm{N}$ bonds of tetrazole rings formation beside the characteristic bands of the residual groups in the structure as presented in Figs. 3 and $4 .{ }^{28}$

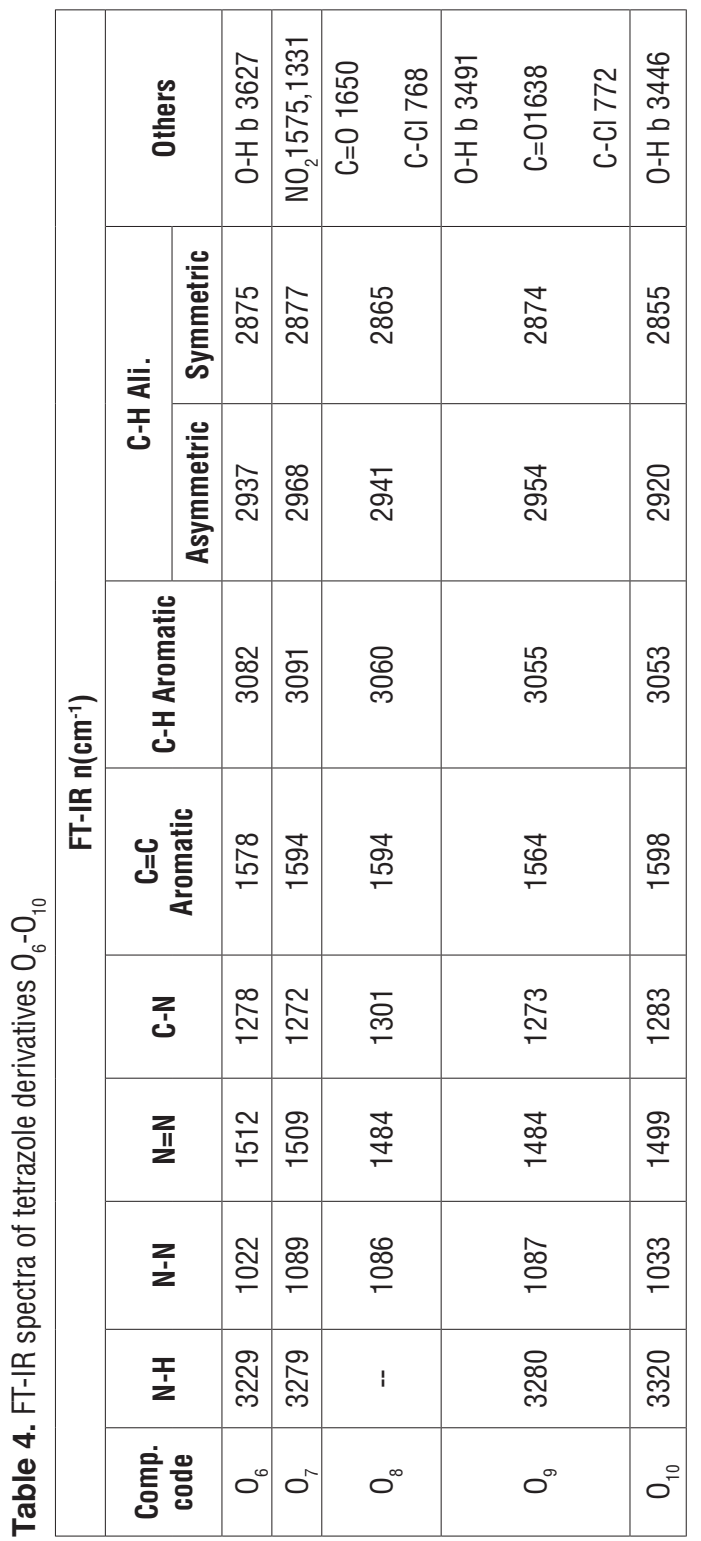




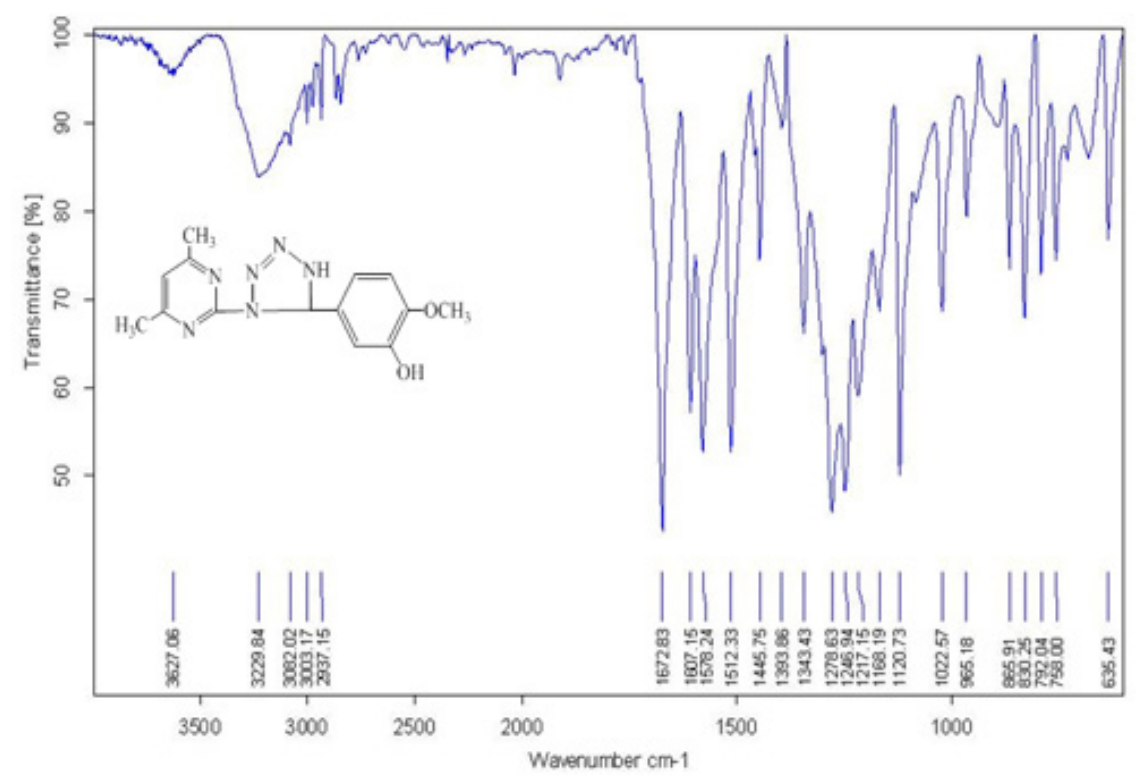

Figure 3. FT-IR spectra of $\mathrm{O}_{6}$

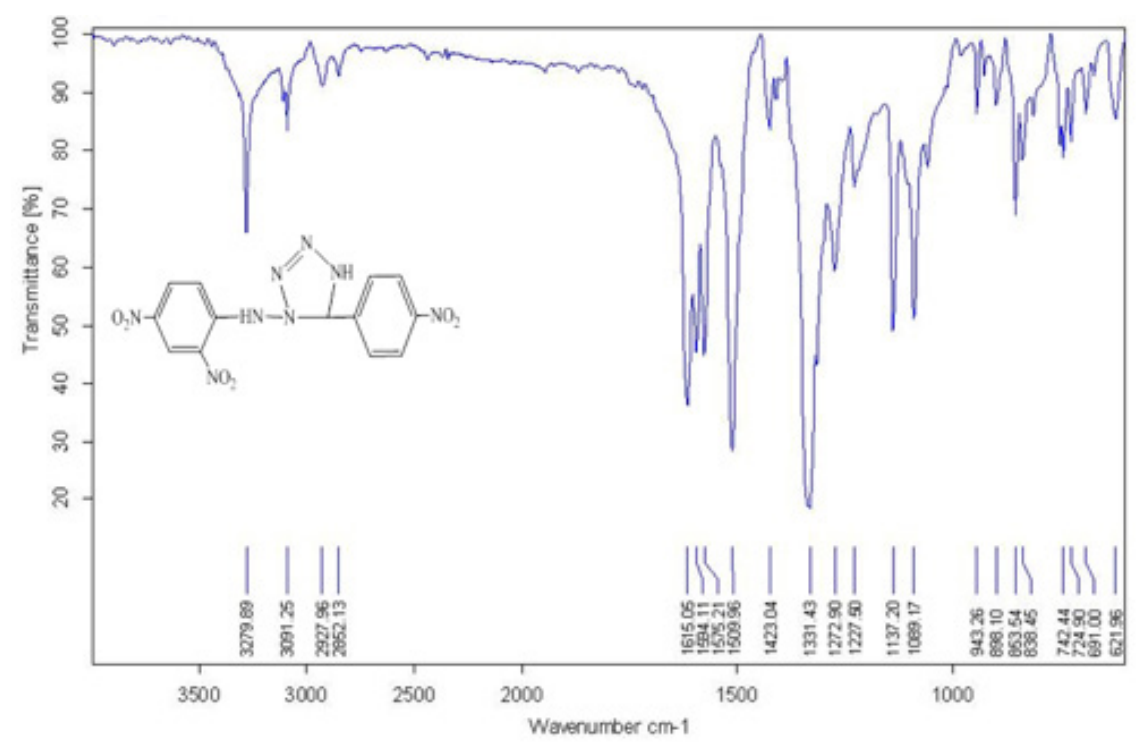

Figure 4. FT-IR spectra of $\mathrm{O}_{7}$

The ${ }^{1} \mathrm{H}-\mathrm{NMR}$ spectrum of compound $\mathrm{O}_{8}$ in DMSO solvent (Fig. 5) showed chemical shifts, $\delta(\mathrm{ppm})$, singlet in 2.46 indicates the presence $3 \mathrm{H}$ of the $(\mathrm{N}-$ $\left.\underline{\mathrm{CH}}_{3}\right)$ group, singlet in 3.20 indicates the presence $3 \mathrm{H}$ of the $\left(=\mathrm{C}-\underline{\mathrm{CH}}_{3}\right)$ group, singlet in 9.57 indicates the presence $1 \mathrm{H}$ of the $(\mathrm{N}-\underline{\mathrm{CH}})$ group, multiplet and doublet of doublet in 7.85-7.36 indicates the presence $9 \mathrm{H}$ of the aromatic pro- 
tons. Spectrum of compound $\mathrm{O}_{9}$ (Fig. 6) showed chemical shifts, $\delta$ (ppm) at: singlet in 2.42 indicates the presence $3 \mathrm{H}$ of the $\left(\mathrm{N}-\underline{\mathrm{CH}}_{3}\right)$ group, singlet in 3.23 indicates the presence $3 \mathrm{H}$ of the $\left(=\mathrm{C}-\mathrm{CH}_{3}\right)$ group, singlet in 6.78 indicates the presence $1 \mathrm{H}$ of the $(-\underline{\mathrm{NH}})$ group, singlet in 9.67 indicates the presence $1 \mathrm{H}(\mathrm{N}$ $\underline{\mathrm{CH}})$ group, singlet in 12.73 indicates the presence $1 \mathrm{H}$ of the $(-\underline{\mathrm{OH}})$ group, multiplet in 7.64-6.93 indicates the presence $8 \mathrm{H}$ of the aromatic protons. ${ }^{31}$ Other chemical shifts of $\mathrm{O}_{6}, \mathrm{O}_{7}$ and $\mathrm{O}_{10}, \delta(\mathrm{ppm})$ are presented in table 5 .

Table 5. The ${ }^{1} \mathrm{H}$-NMR Spectra of tetrazole derivatives $\mathrm{O}_{6}-\mathrm{O}_{10}$ in DMSO

\begin{tabular}{|c|c|}
\hline Comp. code & Chemical Shift $\delta$ ppm \\
\hline $0_{6}$ & $\begin{array}{l}\text { Singlet in } 2.40\left(6 \mathrm{H}, 2 \underline{\mathrm{CH}}_{3}\right) \text {, singlet in } 3.34\left(3 \mathrm{H}, 0-\mathrm{CH}_{3}\right) \text {, singlet in } 7.11(1 \mathrm{H} \text {, } \\
\text { - } \mathrm{NH}) \text {, singlet in } 9.58(1 \mathrm{H}, \mathrm{N}-\mathrm{CH}) \text {, singlet in } 9.77(1 \mathrm{H},-\underline{-\mathrm{H}}) \text {, multiplet and sin- } \\
\text { glet in } 7.42-7.11(4 \mathrm{H} \text {, aromatic protons })\end{array}$ \\
\hline $0_{7}$ & $\begin{array}{l}\text { Singlet in } 3.57(1 \mathrm{H}, \underline{\mathrm{NH} \text { out}}) \text {, singlet in } 8.89(1 \mathrm{H}, \underline{\mathrm{NH}} \text { in), singlet in } 11.86(1 \mathrm{H}, \\
\mathrm{N}-\underline{\mathrm{CH}}) \text { and multiplet and doublet of doublet in } 8.82-8.05 \text { (7H,aromatic protons) }\end{array}$ \\
\hline $0_{8}$ & $\begin{array}{l}\text { Singlet in } 2.46\left(3 \mathrm{H}, \mathrm{N}-\underline{\mathrm{CH}_{3}}\right) \text {, singlet in } 3.20\left(3 \mathrm{H},=\mathrm{C}-\underline{\mathrm{CH}_{3}}\right) \text {, singlet in } 9.57(1 \mathrm{H} \text {, } \\
\mathrm{N}-\underline{\mathrm{CH}}) \text {, multiplet and doublet of doublet in } 7.85-7.36(9 \mathrm{H} \text {, aromatic protons })\end{array}$ \\
\hline $\mathrm{O}_{9}$ & $\begin{array}{l}\text { Singlet in } 2.42\left(3 \mathrm{H}, \mathrm{N}-\mathrm{CH}_{3}\right) \text {, singlet in } 3.23\left(3 \mathrm{H},=\mathrm{C}-\underline{\mathrm{CH}}_{3}\right) \text {, singlet in } 6.78(1 \mathrm{H} \text {, } \\
-\underline{-N H}) \text {, singlet in } 9.67(1 \mathrm{H}, \mathrm{N}-\mathrm{CH}) \text {, singlet in } 12.73(1 \mathrm{H},-\underline{\mathrm{OH}}) \text {, multiplet in } 7.64- \\
6.93(8 \mathrm{H} \text {, aromatic protons) }\end{array}$ \\
\hline $0_{10}$ & $\begin{array}{l}\text { Singlet in } 2.34\left(3 \mathrm{H}, \underline{\mathrm{CH}}_{3}\right) \text {, singlet in } 6.80(1 \mathrm{H},-\underline{-N H}) \text {, singlet in } 8.67(\mathrm{H}, \mathrm{N}-\underline{\mathrm{CH}}) \text {, } \\
\text { singlet in } 13.25(1 \mathrm{H},-\underline{\mathrm{OH}}) \text {, multiplet and doublet of doublet in } 7.66-6.95(8 \mathrm{H} \text {, } \\
\text { aromatic protons) }\end{array}$ \\
\hline
\end{tabular}

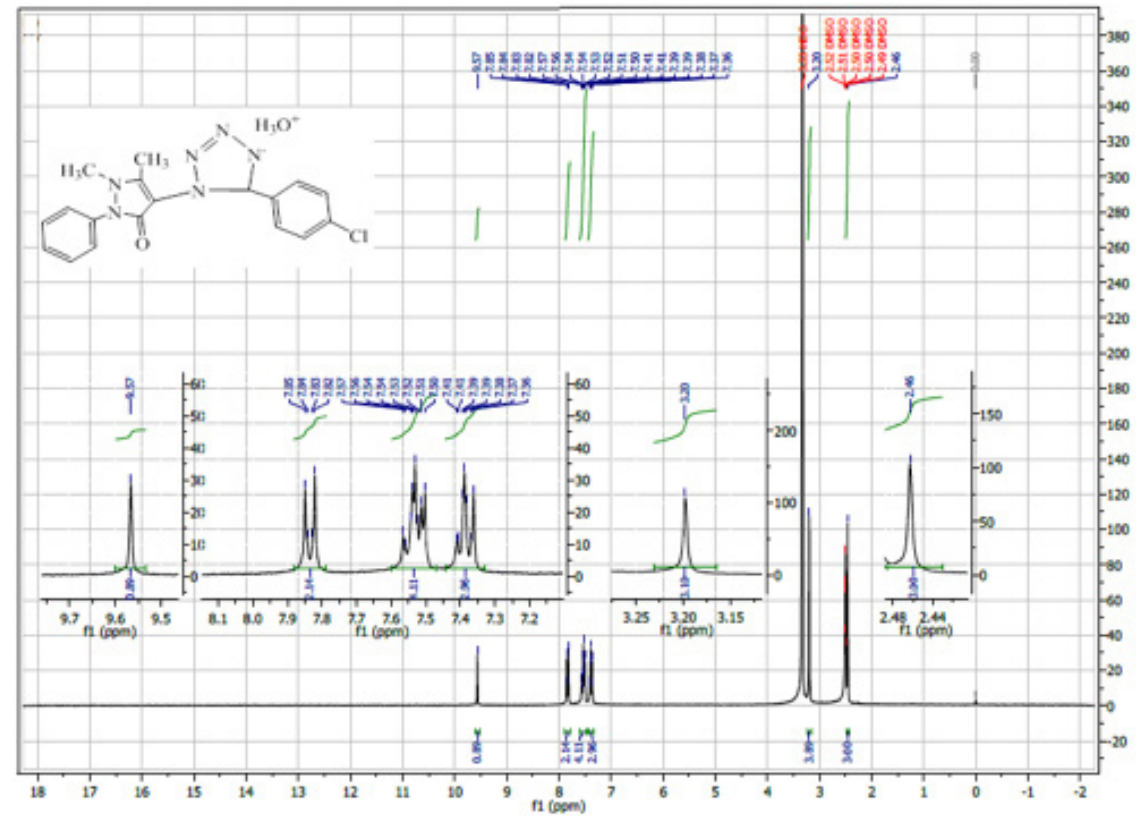

Figure 5. ${ }^{1} \mathrm{H}-\mathrm{NMR}$ Spectra of $\mathrm{O}_{8}$ 


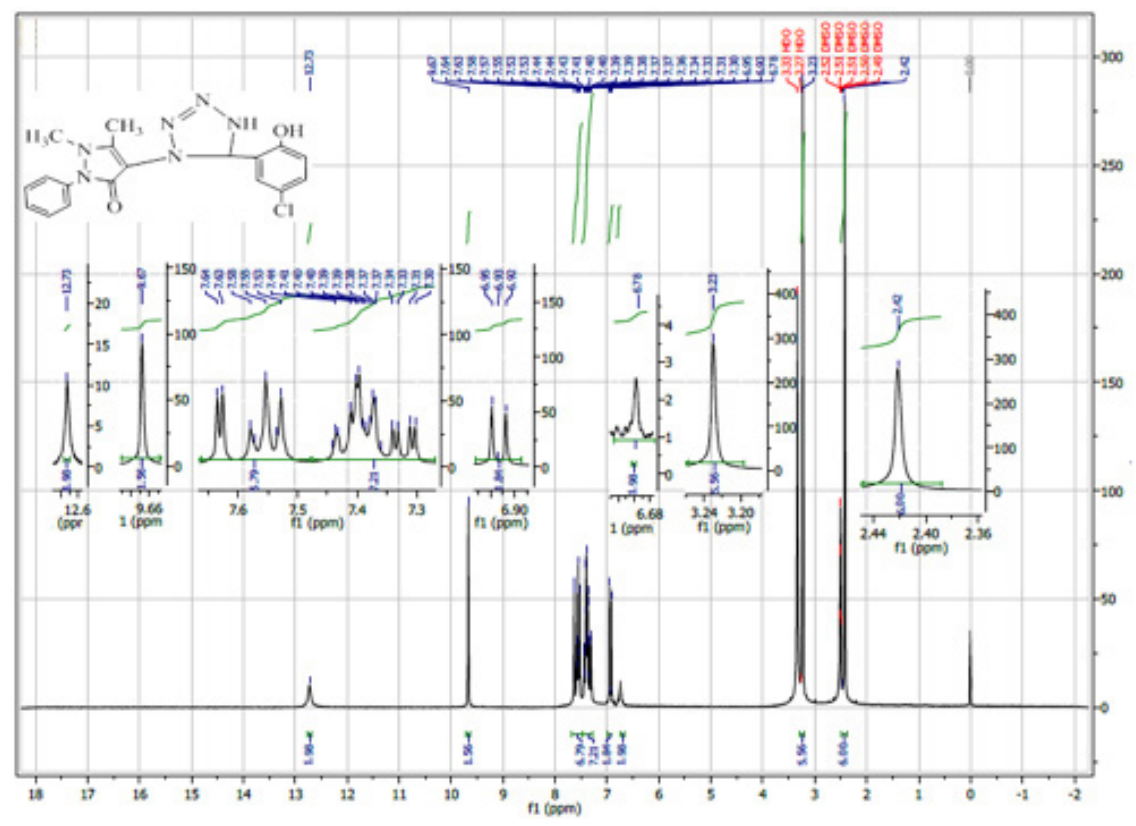

Figure 6. ${ }^{1} \mathrm{H}-\mathrm{NMR}$ Spectra of $\mathrm{O}_{9}$

The ${ }^{13} \mathrm{C}-\mathrm{NMR}$ spectrum of compound $\mathrm{O}_{6}$ in DMSO solvent (Fig. 7) showed chemical shifts, $\delta(\mathrm{ppm}), 37.47$ indicates the presence two groups of $\left(\mathrm{CH}_{3}\right)$, 56.27 indicates the presence one group of $\left(\mathrm{O}-\mathrm{CH}_{3}\right)$ group, 191.91 indicates the presence one group of (N-ㅌH), 112.04-124.94 indicates the presence of aromatic carbons, 130.29-153.80 indicates the presence of pyrimidine carbons. While the spectrum of compound $\mathrm{O}_{9}$ (Fig. 8) exhibited chemical shifts, $\delta$ (ppm), 9.79 indicates the presence one group of $\left(\mathrm{N}-\mathrm{CH}_{3}\right)$ group, 35.01 indicates the presence one group of $\left(=\mathrm{C}-\underline{\mathrm{CH}}_{3}\right), 150.46$ indicates the presence one group of $\left(\mathrm{CH}_{3}-\underline{\mathrm{C}}=\right), 154.78$ indicates the presence one group of $(\mathrm{CO}-\underline{\mathrm{C}}=), 157.80$ indicates the presence one group of $(\mathrm{N}-\underline{\mathrm{C}} \mathrm{H}), 158.59$ indicates the presence one group of (N-CO), 113.96-134.10 indicates the presence of aromatic carbons. ${ }^{32}$ Other chemical Shifts of $\mathrm{O}_{7}, \mathrm{O}_{8}, \mathrm{O}_{10}, \delta(\mathrm{ppm})$ are displayed in table 6 . 
Table 6. The ${ }^{13} \mathrm{C}-\mathrm{NMR}$ spectra of tetrazole derivatives $\mathrm{O}_{6}-\mathrm{O}_{10}$ in DMSO

\begin{tabular}{|c|c|}
\hline Comp. code & Chemical Shift $\delta$ ppm \\
\hline $0_{6}$ & $\begin{array}{l}37.47\left(2 \mathrm{CH}_{3}\right), 56.27\left(0-\mathrm{CH}_{3}\right), 191.91(\mathrm{~N}-\mathrm{CH}), 112.04-124.94 \text { (Aromatic Car- } \\
\text { bons), } 130.29-153.80 \text { (Pyrimidine Carbons) }\end{array}$ \\
\hline $0_{7}$ & $182.49(\mathrm{~N}-\underline{\mathrm{C}} \mathrm{H}), 118.96-125.56$ (Aromatic Carbons) \\
\hline $\mathrm{O}_{8}$ & $\begin{array}{l}\left.10.33(\mathrm{~N}-\underline{\mathrm{CH}})_{3}\right), 35.83\left(=\mathrm{C}-\underline{\mathrm{C}} \mathrm{H}_{3}\right), 144.11\left(\mathrm{CH}_{3}-\underline{\mathrm{C}}=\right), 152.34(\mathrm{CO}-\underline{\mathrm{C}}=), 159.99(\mathrm{~N}- \\
\underline{\mathrm{CH}}), 162.47(\mathrm{~N}-\underline{\mathrm{C}}), 115.08-128.22 \text { (Aromatic Carbons) }\end{array}$ \\
\hline $\mathrm{O}_{9}$ & $\begin{array}{l}9.79\left(\mathrm{~N}-\underline{\mathrm{CH}}_{3}\right), 35.01\left(=\mathrm{C}-\underline{\mathrm{CH}}_{3}\right), 150.46\left(\mathrm{CH}_{3}-\mathrm{C}=\right), 154.78(\mathrm{CO}-\underline{\mathrm{C}}=), 157.80(\mathrm{~N}- \\
\underline{\mathrm{CH}}), 158.59 \text { (N- }-\underline{\mathrm{C}}), 113.96-134.10 \text { (Aromatic Carbons) }\end{array}$ \\
\hline $0_{10}$ & $21.07\left(\underline{\mathrm{C}} \mathrm{H}_{3}\right), 163.00(\mathrm{~N}-\underline{\mathrm{CH}}), 117.00-136.95$ (Aromatic Carbons) \\
\hline
\end{tabular}

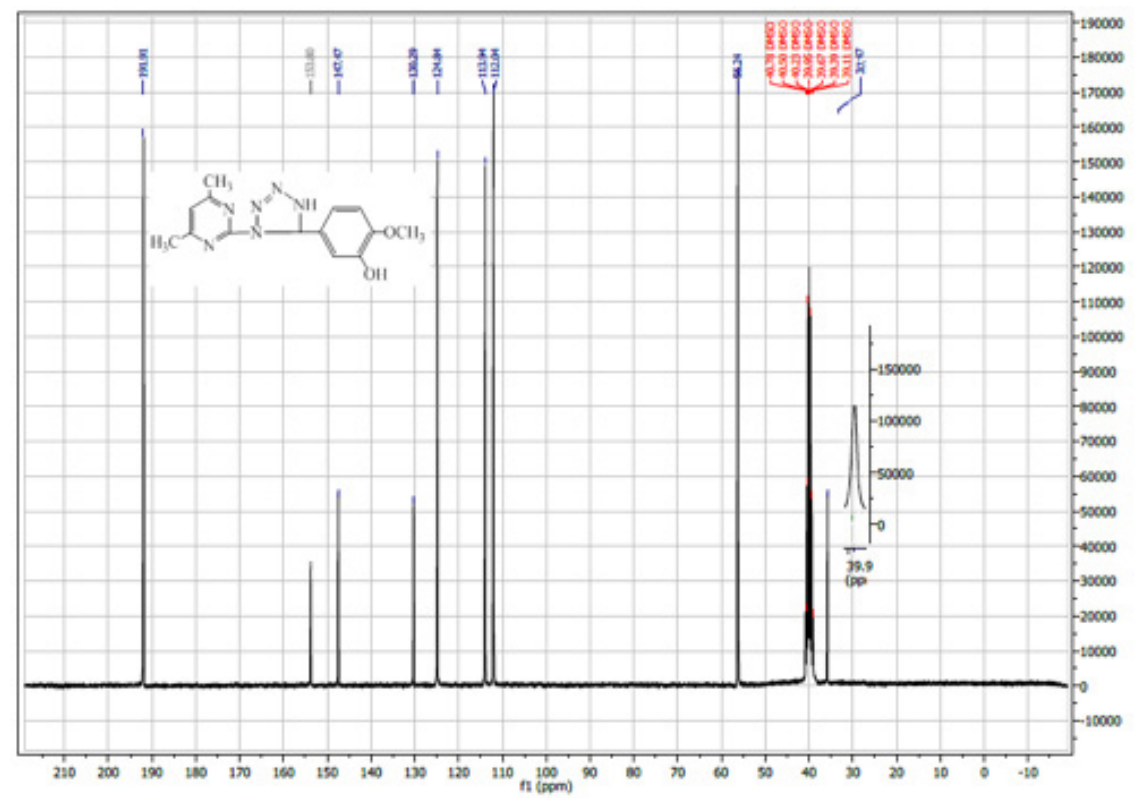

Figure 7. ${ }^{13} \mathrm{C}$-NMR Spectra of $\mathrm{O}_{6}$ 


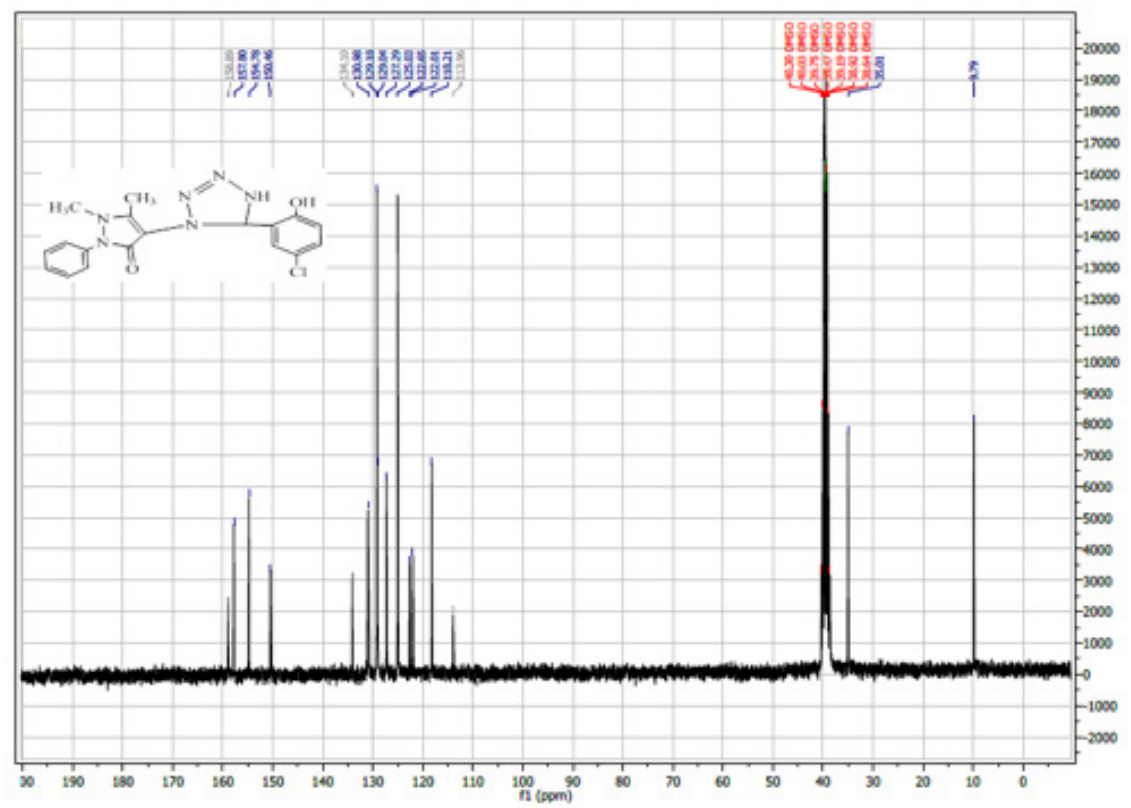

Figure $8 .{ }^{13} \mathrm{C}-\mathrm{NMR}$ Spectra of $\mathrm{O}_{9}$

Products of the reaction of the synthesized imine compounds with sodium azide compound are given in the following equation (Scheme 8):
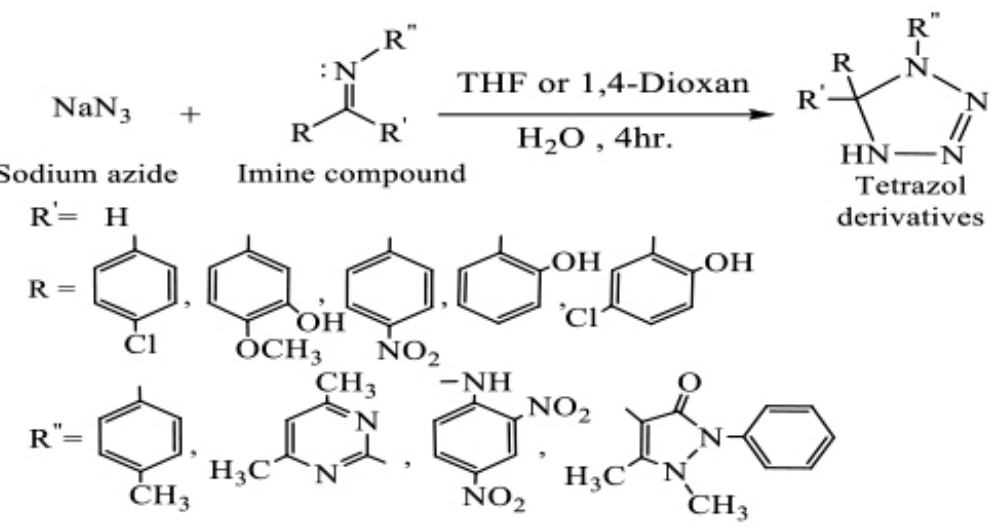

Scheme 8. Structure of the synthesized tetrazole derivatives

It may be concluded that the reaction takes place via the concerted mechanism of the Huisgen 1,3-dipolar cycloaddition mechanism as represented in the following reaction. ${ }^{33}$ See scheme 9. 


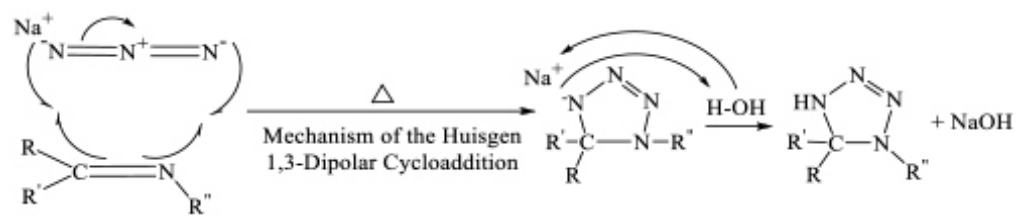

Scheme 9. Mechanism of tetrazole derivatives formation

The results of FT-IR ${ }^{13} \mathrm{C}-\mathrm{NMR}$ and ${ }^{1} \mathrm{H}-\mathrm{NMR}$ showed that the five-ringed compounds were the least obstructed in all preparation processes. Because of the complete clarity in infrared beams and clear signals separated from each another by the resonance spectrum nuclear magnetic of hydrogen and carbon, this is the basis of organic preparation processes.

\section{Anti-Candidal activity}

Zone of inhibition of some human pathogenic fungi was done well-diffusion method to test the potential of the tetrazole derivatives $\mathrm{O}_{6}-\mathrm{O}_{10}$ as shown in Figs. 8 and $9 . \mathrm{O}_{6}$ is the best derivative that has significantly $(p<0.01)$ recorded a stronger influence to inhibit the growth of Candida guilliermondii at an average of the zone of inhibition $14.0 \mathrm{~mm}$. However, $\mathrm{O}_{9}$ derivative recorded the lowest zone of inhibition $7.3 \mathrm{~mm}$ toward the same clinical fungal pathogen. From another hand, $\mathrm{O}_{6}$ showed zone of inhibition $12.0 \mathrm{~mm}$ against Candida zeylanoides. Furthermore, $\mathrm{O}_{6}$ derivative recorded zone of inhibition $11.3 \mathrm{~mm}$ against Candida krusei and Candida albicans. $\mathrm{O}_{10}$ did not inhibit the growth of Candida albicans as shown in Fig. 9. The resistance mechanisms depend on which specific pathways are inhibited by the drugs and the alternative ways available for those pathways that the organisms can modify to get a way around to survive. ${ }^{34}$ Many new metal complexes and new 1,3-oxazepine derivatives had good antibacterial activity. Tetrazole derivatives are important to synthesize inflammatory agents. 35 


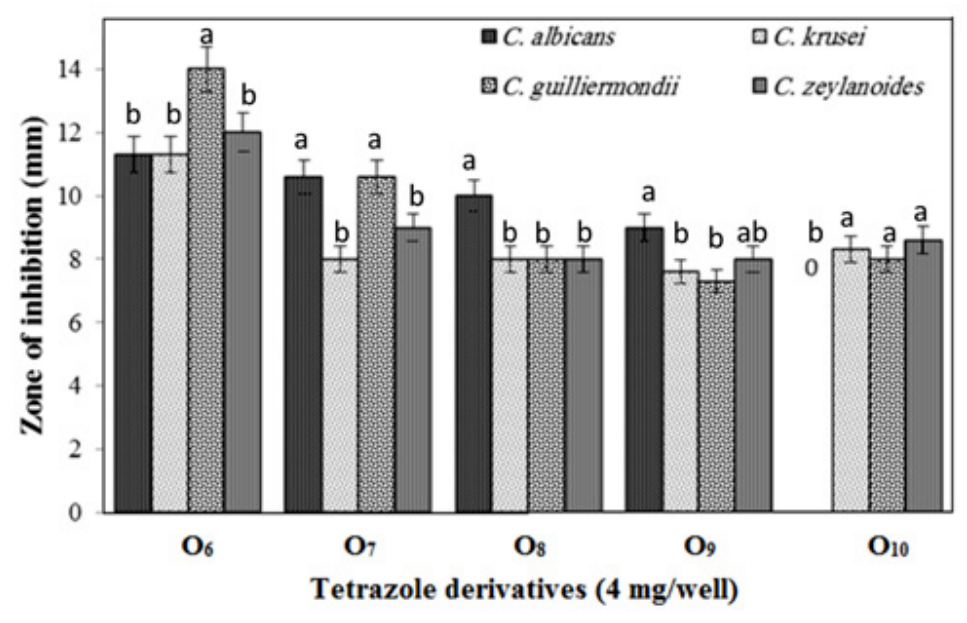

Figure 8. Zone of inhibition of Candida sp. using the synthesized tetrazole derivatives $\mathrm{O}_{6}-\mathrm{O}_{10}$, LDS $(p<0.01)$

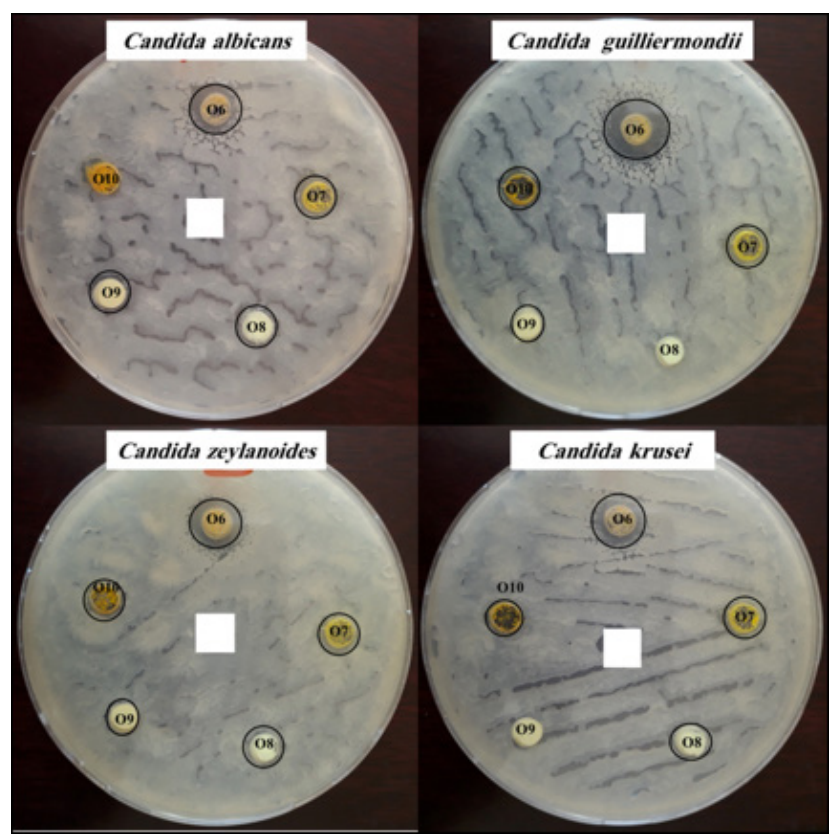

Figure 9. Anti-Candidal activity of the synthesized tetrazole derivatives $\mathrm{O}_{6}-\mathrm{O}_{10}$

This study referees to that preparing derivatives of tetrazole are possible. The results of FT-IR, ${ }^{13} \mathrm{C}-\mathrm{NMR}$ and ${ }^{1} \mathrm{H}-\mathrm{NMR}$ showed that the five-ringed compounds were the least obstructed in all preparation processes. Because of the complete clarity in infrared beams and clear signals separated from each by 
the resonance spectrum nuclear magnetic of hydrogen and carbon, this is the basis of organic preparation processes. $\mathrm{O}_{6}$ is the best derivative that has significantly $(p<0.01)$ recorded a stronger influence to inhibit the growth of Candida guilliermondii at an average of the zone of inhibition $14.0 \mathrm{~mm}$. However, $\mathrm{O}_{9}$ derivative recorded the lowest zone of inhibition $7.3 \mathrm{~mm}$ against Candida guilliermondii. The present work may be helpful in designing more potential antifungal agents for the therapeutic use in the future.

\section{ACKNOWLEDGEMENTS}

Special thanks to Anbar University's President Professor Dr. Khalid Battal Najim for his continuous support to publishing the research in certified international journals. Also, grateful is for Dr. Abdullah Hussein Kshash, Department of Chemistry, College of Education for Pure Sciences, University of Anbar for helping to measurement the FT-IR spectra. 


\section{REFERENCES}

1. Adabiardakani, A.; Hakimi, M.; Kargar, H.; Cinnamaldehyde Schiff Base Derivatives: a Short Review. WA P Journal. 2012, 2, 472-476.

2. Brodowska, K.; Chruścińska, E. Schiff bases - interesting range of applications in various fields of science. CHEMIK. 2014, 68, 129-134.

3. Qin, W.; Long, S.; Panunzio, M.; Biondi, S. Schiff Bases: A Short Survey on an Evergreen Chemistry Tool. Molecules. 2013, 18, 12264-12289.

4. Abid, O.; Muslim, R.; Mohammed, K. Synthesis and Characterization of Novel 1,3,4,9aTetrahydrobenzo[e][1,3]Oxazepin- 5(5aH)-One Derivatives via Cycloaddition Reactions of Schiff Bases J. Uni. Al-Anbar Pure Sci. 2016, 10, 8-18.

5. Ashraf, M.; Mahmood, K.; Wajid, A. Synthesis, Characterization and Biological Activity of Schiff Bases IPCBEE. 2011, 1O, 1-7.

6. Hussain, Z.; Fadhil, Z.; Adil, H.; Khalaf, M.; Abdullah, B.; Yousif, E. Schiff's Bases Containing Sulphamethoxazole Nucleus RJPBCS. 2016, 7, 1500-1510.

7. Mayavel, P.; Thirumurthy, K.; Dineshkumar, S.; Thirunarayanan, G. Perchloric acid catalyzed condensation of amine and aldehydes: Synthesis and antibacterial activities of some aryl (E)-imines, Umcschem. Lxix 2014, 159-179.

8. Al-Jamali, N.; Jameel, M.; Al-Haidari, A. Preparation and invitigation of diazipene, oxazipen compounds through condensation reaction, IJLS. 2013, 1, 13-15.

9. Dahot, M.; Rind, E.; Rafiq, M. Physical and biochemical analysis of sodium azide treated sorghum bicolor (1.) monech, Pak. J. Biotechnol. 2011, 8, 67-72.

10. Mohammed, J. Biological activities importance of tetrazole derivatives, DRJI. 2016, 3, 12796-12804.

11. Varadarasi, D.; Suban, S.; Ramasamy, V.; Kubendirran, K.; Raguraman, J.; Nalilu, S.; Pati, $\mathrm{H}$. Synthesis and evaluation of a series of 1-substituted tetrazole derivatives as antimicrobial agents. Org. Comm. 2010, 3, 45-56.

12. Babu, K.; Prabhakar, V.; Ravindranath, L.; Kishore, N.; Latha, J. Synthesis, Characterization and Study of Antibacterial Activity of Some Novel Substituted Sulphonamide PthalazineTetrazole Derivatives. Res. J. Chem. Environ. Sci. 2016, 4, 51-63.

13. Al-Hakak, Z. A pilot study for the treatment of microbial skin infections caused by bacteria Pseudomonas aeruginosa bacteria that resistance to antibiotic in human and animal by (ND: YAG LASER) technology. Pak. J. Biotechnol. 2017, 14, 417-422.

14. Sial, N.; Abro, S.; Shah, J.; Memon, M. Response of different doses of phosphate fertilizer and phosphate solubilizing_bacteria and mycorrhiza in mungbean (VIGNA RADIATA L.), Pak. J. Biotechnol. 2016, 1, 67-71.

15. El-Sayed, W.; Abdel Megeid, R.; Abbas, H. Synthesis and antimicrobial activity of new 1-[(tetrazol-5-yl)methyl] indole derivatives, their 1,2,4-triazole thioglycosides and acyclic analogs. Arch. Pharm. Res., 2011, 34, 1085-1096.

16. Malik M.; Al-Thabaiti, S. Structure Optimization and Antifungal Screening of Novel Tetrazole Ring Bearing Acyl-Hydrazones, Int. J. Mol. Sci. 2012, 13, 10880-10898.

17. Al-Juburi, R. Synthesis and Characterization of Some Heterocyclic Compounds (Oxazepine, Tetrazole) Derived from Schiff Bases. ANJS. 2012, 15, 60-67.

18. Babu, P.; Ravindranath, L.; Rajesh, D.; Saritha, B. Synthesis of Novel Sultams Containing 
Tetrazole Heterocycles. World J. Pharm. Pharm. Sci. 2016, 5, 929-940.

19. Abid, O.; Tawfeeq, H.; Muslim, R. Synthesis and Characterization of Novel 1,3-Oxazepin$5(1 \mathrm{H})$-One Derivatives via Reaction of Imine Compounds with Isobenzofuran-1(3H)-One. Acta Pharm. Sci. 2017, 55, 43-55.

20. Murhekar, M.; Khadsan, R. Synthesis of Schiff bases by organic free solvent method. $J$. Chem. Pharm. Res. 2011, 3, 846-849.

21. Sabah, H. Synthesis, spectroscopic characterization of schiff bases derived from 4,4'methylen di aniline. Der Pharma Chemica. 2014, 6, 38-41.

22. Berk, B.; Ertaş, M.; Biltekin, S. Synthesis, Antimicrobial Activity Studies and Molecular Property Predictions of Schiff Bases Derived from ortho-Vanillin. Acta Pharm. Sci. 2017, 55, 83-96.

23. Srinivas, B.; Prasanna, B.; Ravinder, M. Synthesis and anti-microbial activity of novel series of N-(substituted phenyl-1H-tetrazol-1-yl)-7-substituted tetrazolo[1,5-a] quinoxalin4yl-amine Derivatives. Der Pharma Chemica. 2016, 8, 84-93.

24. Ravula, P.; Vamaraju, H.; Paturi, M.; Chandra, N.; Kolli, S. Synthesis, in Silico Toxicity Prediction, Molecular Docking, and Evaluation of Novel Pyrazole Derivatives as Potential Antiproliferative Agents. EXCLI Journal. 2016, 15, 187-202.

25. Owaid, M. N.; Raman, J.; Lakshmanan, H.; Al-Saeedi, S. S. S.; Sabaratnam, V.; Al-Assaffii, I. A. Mycosynthesis of silver nanoparticles from Pleurotus cornucopiae var. citrinopileatus and its inhibitory effects against Candida sp. Mater. Lett. 2015, 153, 186-190.

26. Owaid, M.; Muslim, R.; Hamad, H. Mycosynthesis of Silver Nanoparticles using Terminia sp. Desert Truffle, Pezizaceae, and their Antibacterial Activity. JJBS. 2018, 11, 401-405.

27. Muslim, R.; Tawfeeq, H.; Owaid, M.; Abid, O. Synthesis, Characterization and Evaluation of Antifungal Activity of Seven-Membered Heterocycles. Acta Pharm. Sci. 2018, 56, 39-57.

28. Silverstein, R.; Webster, F.; Kiemle, D. Spectrometric identification of organic compounds, 7th edition, John Wiley and sons, Inc., 2005, 72-126.

29. J. Simek, Organic Chemistry, 8th edition, Pearson education, Inc., 2013, 412-414.

30. Abid, O.; Muslim, R.; Mohammed, K. Synthesis and Characterization of Novel 1,3-Oxazepin-4-Ones Derivatives via Schiff Bases Reactions with Phthalide. J. Uni. Anbar Pure Sci. 2016, 10, 1-9.

31. Silverstein, R.; Webster, F.; Kiemle, D. Spectrometric identification of organic compounds, 7th edition, John Wiley and sons, Inc., 2005, 127-202.

32. Mistry, B. A Handbook of spectroscopic Data chemistry, edition 2009, Oxford book company Jaipor India, Mehra Offset Printers, Delhi, 2009, 99-127.

33. Das, R.; Majumdar, N.; Lahiri, A. A review on 1,3-dipolar cycloaddition reactions in bioconjugation and it's importance in pharmaceutical chemistry. IJRPC. 2014, 4, 467-472.

34. Tenover, F. Mechanisms of antimicrobial resistance in bacteria, Am. J. Med. 2006, 119, 3-10.

35. M. F. El Shehry, J. Balzarini, C. Meier, Synthesis of 3-((2, 4-dichlorophenoxy) methyl)-1, 2, 4-triazolo (thiadiazoles and thiadiazines) as anti-inflammatory and molluscicidal agents., Synthesis. 2009, 5, 841-847. 